\title{
Organizational Leadership Styles and Utilization of Evaluation Results
}

\author{
Edwin Ochieng Okul ${ }^{1} \&$ Raphael O. Nyonje ${ }^{2}$ \\ ${ }^{1}$ Candidate, The University of Nairobi, Kenya \\ ${ }^{2}$ School of Open, Distance and eLearning, The University of Nairobi, Kenya \\ Correspondence: Edwin Ochieng Okul, The University of Nairobi, P.O. Box 84 - 40123, Kisumu, Kenya. E-mail: \\ edwin.okul@gmail.com
}

Received: April 14, 2021

Accepted: August 15, 2021

Online Published: September 19, 2021

doi:10.5539/jms.v11n2p151

URL: https://doi.org/10.5539/jms.v11n2p151

\begin{abstract}
The greatest concern in programme management, given the potential of programme or project evaluations to inform decision-making, remains how to ensure the results of an evaluation are used for the intended purpose and how information from an evaluation process and/or the products are applied to practices and decision-making processes. This article presents a research that sought to explore the degree to which organizational leadership style impacts the use of evaluation findings for programme improvement. Based on the pragmatic paradigm and informed by the Utilization Focused Evaluation Model and Knowledge Use Theory, the research adopted a descriptive and correlational design using mixed methods. The study's sample comprised of 232 project staff from Non-Governmental Organizations (NGOs) based in Kisumu Central Sub-County, Kenya. Content analysis method that involved coding and identifying themes from respondents' responses was used to analyse the qualitative data obtained from key informant interviews. Both percentages and frequencies were used to summarize the quantitative data. The instrument reliability was assessed through pilot testing and Cronbach alpha of 0.908 attained. A hypotheses $\mathrm{H}_{1}$ : Leadership style does not significantly influence utilization of evaluation results was tested at $\alpha=.05$ level of significance, but it was rejected because $\mathrm{P}=0.000<0.05$. The study established a statistically significant relationship between organizational leadership style and the utilization of evaluation results. In so doing, it reinforces the existing literature by helping to understand the way organizational leadership style influences the utilization of evaluation results. It fills a gap in the literature, thereby contributes to the appreciation of the factors that enhance and predict the utilization of evaluation results.
\end{abstract}

Keywords: project evaluation, organizational leadership style, evaluation utilization

\section{Introduction}

The utilization of evaluation results has been among the greatest challenges in the field of evaluation. Accordingly, most evaluations do not achieve their primary goals which is social betterment (Henry, 2003; Mark, et al., 2000). While this might appear normal, it is ironical to note that very little is known about the utilization of results yet resources are spent to evaluate development programmes. The Utilization Focused Evaluation emanates from the desire in the evaluation arena to conduct useful evaluations. Although the implementation of utilization focused evaluation may appear simple, it is normally hindered by several factors, with organizational challenges being among the main ones (Ramírez et al., 2015).

The development of evaluation practice and interest in its use has varied globally. In USA, for instance, evaluation became a relevant subject in the 1960s after the national government lost huge sums of money invested in social programmes, yet nothing or very little was realised from the programmes (Stufflebeam et al., 2000). In Canada, it is accepted by government as a significant management tool for enhancing performance in government programmes as well as projects (Stolyarenko, 2014). In Europe, evaluation practices vary across nations, but they are at advanced stages in countries such as Finland, Germany, UK, France, Norway, Denmark and Netherlands (BaTall, 2009). Its use is notable in Europe in operational levels, particularly in expenditure programmes (EPEC, 2005). Most of the countries in South East Asia have tried to embrace evaluation, but their focus has been on project planning and development (Magno, 2011). As a result, although most of the governments throughout the world have focused their attention on developing systems for planning and implementing projects, very little has been done to develop strong evaluation practices (Lowden, 2005). 
Evaluation in Malaysia assumes an integrated approach and is entrenched within the Integrated Results Based Management (IRBM) since the 1990s. As experience demonstrates in Indonesia, it is only when the government became aware of the evaluation purposes and started feeling the public pressure to deliver better services thus developed a demand for evaluation, that the institutionalization of the evaluation function became effective (Boyle \& Lemaire, 1999). In South Africa, programme evaluation emerged due to the need to evaluate NGO's programs (Mouton, 2010). A larger part of evaluation started in the 2000s due to increased funding (Goldman et al., 2015). The earliest M\&E system in government began with the creation of the Department of Planning, Monitoring and Evaluation (DPME). Nonetheless, the department was predominantly compliance-based, notably in terms of responsibility to National Treasury and the Auditor General (Phillips et al., 2014). Accordingly, for evaluation to be utilised in the country, it was crucial to change this tradition. Nonetheless, the potential for those in government to utilise evaluations was restricted (Mouton, 2010).

In Kenya, as in most developing countries, programme evaluation, which is largely practiced in the public sector is yet to reach satisfactory levels of application at the government level (Republic of Kenya, 2014). However, effort has been directed towards monitoring and evaluation. This dates back to 1983 when a Monitoring and Evaluation framework was proposed for the District Focus for Rural Development strategy and in the 1990s when it was applied to Poverty Eradication Strategy (Kirori, 2015). The latest efforts have been in the development of a National Integrated Monitoring and Evaluation System aimed at monitoring the progress of the Economic Recovery Strategy (Republic of Kenya, 2017). Accordingly, central M\&E programmes in project management both at national and local level has been a recent development in the country (Republic of Kenya, 2017). Nonetheless, earlier in 2004, the government had introduced Results Based Management (RBM) in the public sector as a planning policy aimed at enhancing overall performance, governance and service delivery. Performance contracts were later added as control measures for ensuring that projects attained intended objectives within pre-determined timelines and pre-negotiated targets (Ochanda, 2005).

The Kisumu-based NGOs have over the years undertaken evaluation activities, and although some of the evaluations are focused on analyzing projects' impact, they are part of obligatory requirement for their donor funded projects. Donors use the evaluations to assess the extent to which NGOs spend funds effectively (African Water Facility, 2014; USAID, 2014; Concern Worldwide, 2014). In this respect, the utilization of the evaluation results is thereby an important outcome for most of the projects.

\subsection{Project Evaluation}

Project evaluation is any activity aimed at assessing the merits of a project. It is a scientific technique employed to determine the extent to which a project achieves desired results in a particular context. Most of the people and organizations use it to determine projects' worth in line with intended purposes (Guskey, 2000).

\subsection{Evaluation Utilization}

Gary and Melvin (2003) claim that the term "utilization" is normally equated to the term "use". Accordingly, for a long time, both terms have been utilised almost in the same way. In view of this, the current study does not attempt to distinguish the terms. Studies on evaluation use identify Process use, Pervasive use, Instrumental use, and Conceptual use as some of the categories of evaluation utilization. Conceptual use occurs when evaluation findings enable programme staffs to understand and perceive programmes in new ways (Fleisher \& Christie, 2009). Persuasive use entails educating, informing and persuading others particularly stakeholders and decision makers to view projects or programs in a specified way (Johnson et al., 2009). Process use refers to the organizational, programme, behavioural and cognitive changes that result either directly or indirectly from engaging in evaluation processes aimed at enabling users to learn to think evaluatively (Patton, 2008). The Instrumental use occurs when changes are made on programmes based on evaluation findings (Shulha \& Cousins, 1997; McCormick, 1997).

This study considered multiple definitions for evaluation utilization as it explored the influence of organizational leadership style and three definitions that reverberated for the researcher are those of Alkin (2004) who interpreted use as "the ways in which an evaluation and information from the evaluation impacts the programme that is being evaluated"; Patton (2008) who interpreted use as "how real people in the real world apply evaluation findings and experiences" and Johnson et al. (2009) who regarded use as "the application of evaluation process, products, or findings to produce an effect".

\subsection{Organizational Leadership Style}

Leadership is a process by way of which an executive can direct, guide and affect the conduct and work of others towards accomplishment of goals in a given situation. It is the potential of a supervisor to cause in the 
subordinates to work with self-assurance and zeal, the capability to influence the behaviour of others. It is also the capability to steer a group towards the idea of an intention (Cousins et al., 2004). In instances where leaders want to see evaluation outcomes put to use, they will possibly have an influence on their organizations in that direction.

Among the most significant ways by which leadership is assessed are through such fundamentals as leadership styles, behavior, environment/circumstance and characteristic through which leadership is demonstrated. While leaders may appear similar because of the characteristics they share with each other, they manifest their unique characteristics differently. The current study utilises the term leadership style to describe the way leaders manage their respective organizations.

Some of the theories used to describe leaders relate to leaders' emotional, competency, contingency, behaviour, traits and visions. Previously, it was considered that certain human beings had been born to be leaders. This position was modified by the behavioural or styles principle that identified six parameters that were used to assess leadership. The six parameters included participation in decision-making processes, authority, production, challenge, flexibility in opposition to regulation and decision-taking (Muller \& Turner, 2005). Then there is the contingency concept which is concerned with special instances of the leadership. The visionary or charismatic school was introduced by those studying leaders who effectively controlled their organizations through change.

Three organizational leadership styles; democratic, autocratic and laissez faire organizational leadership styles were introduced by Yukl (1989). The autocratic leaders do not engage their subordinates in the decision-making process; the laissez-faire leaders though allow the subordinates to contribute to the decision-making process whereas the democratic leaders allow subordinates to participate in decision making processes (Ryan \& Tipu, 2013). The transactional and transformational leadership styles were originally developed by Burns (1978), but they were refined by Bass $(1985,1990)$. This later model contained three styles: transactional, transformational, and laissez-faire (Bass \& Avolio, 1994). For the purpose of this study, autocratic leadership, laissez-faire leadership, democratic leadership, transformational and transactional Organizational leadership styles are the focus.

\section{Literature Review}

Leadership in the organization has a role with respect to enabling employees to elicit and learn behaviours consistent with change. This includes the role of leadership in articulating organizational mission and vision as an organization committed to learning (Ali \& Ali, 2017). Leaders play critical roles in enabling their subordinates to perform tasks effectively. Where the organization's leadership style supports and is involved in evaluation activities, the process is likely to be successful and useful. Accordingly, the involvement of management teams in organizational leadership enhances the acceptance of M\&E processes and subsequently the use of its findings in organizational processes (Khan et al., 2014). The organization's management plays an important function in resource allocation, evaluation design, communication of evaluation results and decision making which affect evaluation activities. Their devotion to the implementation of evaluation recommendations is thereby vital because it ensures that adequate resources are allocated to evaluations.

The aristocratic leaders provide clear outline of what, when and how things need to be done. They ensure that there is distinct difference between leaders and the people they lead. The authoritarian leaders, on the other hand, make decisions independently without necessarily looking for input from the people they lead. The autocratic leaders on their part retain considerable power in decision making processes; as such, they rarely consult other members of staff to contribute in decision making process. In so doing, they expect staff members to follow their guidelines without expressing their views (Dessler \& Starke, 2004).

The laissez-faire leader, also referred to as delegative leadership, allows group members to make decisions. Although the leadership style is good, it normally results to low output among project staff. Such project managers are least attentive to the completion of tasks and efficiency. They are particularly "hands-off" in approach to managing so as to push for collective critical thinking and problem-solving tactics without allowing group members to rely on the leader for final decision (Dessler \& Starke, 2004). Such project managers allow complete freedom for followers to make decisions expecting them to solve problems on their own. While the leadership style is good because it delegates decision making process to group members, it does not direct members to specific areas due to the freedom they enjoy in making their decisions without team leaders getting involved in setting goals and resolving problems as they arise.

Democratic leadership style focuses much attention on upholding group efficiency in task accomplishment. The style encourages group members to express their feelings and ideas freely believing that such an environment results in greater commitment and creativity (D'Souza, 2006). Despite encouraging members to express 
themselves freely, the democratic leader retains the ultimate power to make decisions. Even though the exercise might appear trivial, it engages team members thereby promote their creativity. The democratic leaders adopt such a practice because they understand the importance of engaging subordinates in solving the problems they encounter in their job processes (Larfela, 2010).

The transformational leadership style is focused on changing the norms by creating new visions, mobilizing commitment from team members and inspiring followers to be results-oriented (Pieterse et al., 2010). Transformational leadership style focuses on staff progress and needs. Project managers with transformational management style are extra concerned with the improvement of employees' value system and inspiring degrees of commitment to enhancing competencies among employees (Ismail et al., 2009). In so doing, they encourage followers to view challenges from different perspectives, guide and encourage them to approach challenges differently. The transformational leader also communicates imaginatively, are prescient and at the same time as inspiring. To a large extent, the transformational leadership is the best style for managing projects because it is focused on positive changes. It helps project managers to plan, coordinate and implement changes (Chaplowe, 2008).

The transformational leader's involvement in project implementation enhances the mobilization of resources, learning and ownership. It also ensures that the information obtained throughout the project implementation is utilised for future evaluation and intervention in decision making processes (Chaplowe, 2008). Evaluation results should be utilized to enhance projects' operations and strategy. Wanjiru (2013) observes that the role of leaders in $\mathrm{M} \& \mathrm{E}$ is vital to ensuring that processes are successful and effective. The management teams should use information obtained from exercises to enhance their decision-making processes. Transformational leadership is therefore likely to look for what has been done well and what has not progressed well towards intended results.

The transactional leadership style focus attention on rewarding followers who meet performance targets and punishing the ones who do not meet targets (Trottier et al., 2008). Transactional leadership tends to rely more on "trades-offs" between followers and leaders. Here, project staffs are rewarded for meeting pre-determined goals and performance criteria (Trottier et al., 2008). A study by Scott (2003) determined that most of the leaders that adopt transactional leadership style start by evaluating the link between reward and performance and then determine an appropriate response that would encourage followers to improve performance.

Cousins et al. (2006) examined the extent to which schools use evaluation and found that instrumental and conceptual uses of evaluative inquiry occur in school settings in informal ways and support decision making. They established that the important factors that supported use included development of an appreciation for evaluation based on experienced benefits and school leadership. The studies were based on evaluators' perspective, a choice that reflects their attempts to describe the context of the evaluation and the complexity of factors influencing use. These were multiple case studies based on observations of the researchers and found that school leadership is important in evaluation use. While the case studies provide rich details about the evaluation process, it is difficult to determine the strength of the factors influencing use and even to determine the direction of the relationships between factors influencing use.

In a broad-based study that evaluated the projects that the Swiss Federal Administration completed between 1999 and 2002, Balthasar (2009) concluded that orientation toward the obligations of the organization leadership, who are the potential users, is commonly a vital condition for evaluation utilization. The study documented and analysed the historical development for evaluation utilization carried out under different general conditions. These studies were basically qualitative research based on literature reviews and content analysis. The case studies were evaluated using quantitative comparative analysis (QCA) methodology. An important factor in ensuring the use of evaluation findings, the study concluded, is not necessarily the quality of the evaluation but the existence of a leader with commitment to implementing its findings. Relying heavily on the interpretivist paradigm, the study employed qualitative methods at the expense of the mixed methods approach. The study should have recognized the themes connecting quantitative ('constructivist' paradigm) and qualitative research; hence, acknowledge the importance of combining quantitative methods with qualitative ones (Guba, 1990). This would have prevented the study being subjective, with the researchers' personal experiences, beliefs, and values being profoundly fused into the research design and analysis of data. The use of mixed method research would have strengthened the study's findings thereby overcome the weaknesses of qualitative and quantitative research.

\subsection{Theoretical Framework}

The current study was based on the Utilization Focused Evaluation Model; and supported by Knowledge Use Theory. 


\subsubsection{Utilization Focused Evaluation Model}

The current study is anchored on the Utilization Focused Evaluation (UFE) model. Alkin (2004) claims that most of the attributes that are characteristically termed as "theories" in evaluation can be referred to as frameworks or models. The evaluation use theories address themselves to the way information is used by the people who obtained the information (Christie \& Alkin, 2008; Alkin, 2004). Patton's Utilization Focused Evaluation (UFE) is an outstanding theoretical explanation of use. Consequently, it is widely used by evaluation researches (Alkin, 2004; Stufflebeam \& Shinkfield, 2007). The theory is founded on the notion that evaluations should be assessed on their actual use and utility. Accordingly, evaluators should design and facilitate evaluation processes bearing in mind the impact of what is done right from the start to the end (Nyonje et al., 2002). The implication is the utilization should be focused on intended use by the people using its results (Patton, 2008).

\subsubsection{Knowledge Use Theory}

The evaluation results may also be regarded as knowledge. Shadish, Cook and Leviton (1991) identify knowledge use as a fundamental issue that undergird the practical evaluation theory. Shadish, Cook and Leviton (1991) proposed an evaluation theory model consisting of five components. The knowledge use and knowledge construction were among the five components. Shadish, Cook and Leviton (1991) argue that the knowledge obtained from evaluation processes should be utilised to solve social problems. They claim that the usefulness of the knowledge obtained from evaluation process should be the basis for justifying the amount of resources spent on evaluation. They allege that evaluation should inform the need for new knowledge.

\section{Methodology}

The current study is both correlational and descriptive in nature. From a pragmatism paradigm, it utilizes mixed methods to evaluate the influence of organizational leadership style on the utilization of evaluation results. The decision to combine the qualitative and quantitative research methods was based on the inferential and descriptive data analysis methods. Nonetheless, most of previous studies on evaluation use have been literature reviews and case studies (Goh et al., 1997; Johnson et al., 2009; Preskill et al., 2003; Shulha \& Cousins, 1997; Greene, 1988).

The study's sampling unit consisted of project staff obtained from a target population of 585 staff members from 117 Kisumu-based NGOs. A sample of 232 staff members was determined using the hypergeometrical distribution formula and Krejcie and Morgan tables (Krejcie \& Morgan, 1970). The research participants were purposively selected from project coordinators, NGOs' field assistants, project assistants, programme managers and executive directors. Simple random sampling method was utilised to select two members from the list of five staff members developed for the 117 NGOs. Questionnaire was utilized to obtain data from the respondents, but it was complemented by interview schedules utilized to obtain data from key informants.

Pilot testing was done on 23 project staffs from the NGOs in a neighbouring county. The 23 staffs were approximately $10 \%$ of the sample that Mugenda and Mugenda (2003) recommend for pilot testing. The research questions with relatively low Cronbach alphas were revised to enhance their clarity. Cronbach alpha was thereby utilised to assess the instruments' reliability (Cronbach \& Azuma, 1962). The analysis established that the questionnaire had a 0.908 reliability coefficient that was considered reliable. This was in line with Cronbach and Azuma (1962) who regard a 0.7 coefficient and above as sufficient for an instrument.

Pearson product-moment correlations coefficients were determined to assess the link between organizational leadership style and the utilization of evaluation results by the Kisumu central sub-county-based NGOs. The Alternate Hypothesis, $\mathrm{H}_{1}$ "There is significant relationship between organizational leadership style and utilization of evaluation results in NGOs in Kisumu central sub-county" was assessed against a null hypothesis that presumed that the link between them was not statistically significant. An alpha of $0.05(\alpha=0.05)$ was used as the level of significance. In line with Sekaran (2006) the null hypothesis was rejected if the $\alpha$-value was less than 0.05 , but for values greater than 0.05 , it was accepted. The decision was based on a two-tailed test.

The alternative hypothesis was as follows;

Hypothesis; $\mathbf{H}_{1}$ : There is significant relationship between Organizational leadership style and Utilization of evaluation results among the Kisumu central sub-county-based NGOs.

Utilization of evaluation results $=f$ (Organizational leadership style, random error)

$$
Y_{j}=\beta_{0+} \beta_{2} X_{1+} \varepsilon i
$$

Where $\beta_{0}$ was the Population's regression constant, $X_{1}$ is Organizational leadership style, $\beta_{i}$ is the regression coefficient of Organizational leadership style and $\varepsilon$ is the Model error variable. 
The regression model was utilized to make inferences about the target population based on the sample. The simple linear regression evaluated the influence of organizational leadership style on the utilization of evaluation results.

\section{Findings and Discussions}

Only 226 questionnaires out of the 232 that were administered were filled in the right way; hence, the response rate was $97.4 \%$ as Table 1 depicts.

Table 1. Questionnaire response rate

\begin{tabular}{llll}
\hline Number of Project staff & Questionnaires issued & Total questionnaire returned & Percentage of Response \\
\hline 232 & 232 & 226 & 97.5 \\
\hline
\end{tabular}

The $97.4 \%$ response rate was considered sufficient for the study because it was above the $50 \%$ mark, which is considered sufficient for any study to generalize findings to target population (Orodho, 2009).

\subsection{Utilization of Evaluation Results}

The views of the project staff about the utilizations of evaluation results in NGOs were assessed using ten statements. The utilization of evaluation results was the study's dependent variable. A 5-point Likert scale with Strongly agree $(\mathrm{SA})=5$; Agree $(A)=4$; Neutral $(N)=3$; Disagree $(D)=2$ and Strongly disagree $(\mathrm{SD})=1$ was utilized to assess the extent to which the respondents agreed or disagreed with the statements. Table 2 presents the study's findings on the utilization of evaluation results.

Table 2. Utilization of evaluation results

\begin{tabular}{|c|c|c|c|c|c|c|c|}
\hline ITEMS & SA & $\mathbf{A}$ & $\mathbf{N}$ & D & SD & Mean & Std. Dev. \\
\hline \multicolumn{8}{|l|}{ INSTRUMENTAL USE } \\
\hline $\begin{array}{l}\text { My organization used evaluation results } \\
\text { to increase funding }\end{array}$ & $60(26.5 \%)$ & $79(35.0 \%)$ & $48(21.2 \%)$ & $31(13.8 \%)$ & $8(3.5 \%)$ & 3.67 & 1.115 \\
\hline $\begin{array}{l}\text { My organization used evaluation results } \\
\text { to scale up our project }\end{array}$ & $74(33.1 \%)$ & $88(38.5 \%)$ & $40(17.7 \%)$ & $19(8.5 \%)$ & $5(2.2 \%)$ & 4.09 & 2.854 \\
\hline $\begin{array}{l}\text { My organization used evaluation results } \\
\text { to restructure our project }\end{array}$ & $82(33.6 \%)$ & $94(41.6 \%)$ & $30(15.9 \%)$ & $15(6.7 \%)$ & $5(2.2 \%)$ & 3.98 & 0.982 \\
\hline \multicolumn{8}{|l|}{ CONCEPTUAL USE } \\
\hline $\begin{array}{l}\text { From the findings of our last } \\
\text { evaluation, I understand the project } \\
\text { differently }\end{array}$ & $75(33.2 \%)$ & $85(37.6 \%)$ & $53(23.4 \%)$ & $4(1.8 \%)$ & $9(4.0 \%)$ & 3.96 & 0.942 \\
\hline $\begin{array}{l}\text { From the findings of our last } \\
\text { evaluation, I have learnt more about } \\
\text { the project }\end{array}$ & $83(36.7 \%)$ & $84(37.2 \%)$ & $33(14.6 \%)$ & $22(9.7 \%)$ & $4(1.8 \%)$ & 3.97 & 1.032 \\
\hline $\begin{array}{l}\text { From the findings of our last } \\
\text { evaluation, I understand other's } \\
\text { perception of the programme better }\end{array}$ & $75(33.2 \%)$ & $96(42.5 \%)$ & $26(11.5 \%)$ & $12(5.3 \%)$ & $17(7.5 \%)$ & 3.88 & 1.153 \\
\hline PURSUASIVE USE & & & & & & & \\
\hline $\begin{array}{l}\text { Results from our last evaluation have } \\
\text { persuaded others to be interested in our } \\
\text { project }\end{array}$ & $71(31.4 \%)$ & $86(38.1 \%)$ & $35(15.5 \%)$ & $18(8.0 \%)$ & $16(7.0 \%)$ & 3.79 & 1.177 \\
\hline $\begin{array}{l}\text { Results from our last evaluation have } \\
\text { persuaded others to fund raise for our } \\
\text { project }\end{array}$ & $50(22.1 \%)$ & $72(31.9 \%)$ & $52(23 \%)$ & $30(13.3 \%)$ & $22(9.7 \%)$ & 3.43 & 1.243 \\
\hline $\begin{array}{l}\text { I applied a new skill(s) learned as a } \\
\text { result of conducting the evaluation }\end{array}$ & $76(33.6 \%)$ & $86(38.1 \%)$ & $28(12.4 \%)$ & $26(11.5 \%)$ & $10(4.4 \%)$ & 3.85 & 1.141 \\
\hline $\begin{array}{l}\text { I applied lesson learned as a result of } \\
\text { conducting the evaluation }\end{array}$ & $79(35 \%)$ & $80(35.4 \%)$ & $38(16.8 \%)$ & $20(8.8 \%)$ & $9(4.0 \%)$ & 3.88 & 1.106 \\
\hline $\begin{array}{l}\text { COMPOSITE UTILIZATION OF } \\
\text { EVALUATION RESULTS }\end{array}$ & $72(31.6 \%)$ & $85(37.6 \%)$ & $39(17.3 \%)$ & $20(8.8 \%)$ & $10(4.4 \%)$ & 3.85 & 1.382 \\
\hline
\end{tabular}


Table 2 shows that about $72(31.6 \%)$ of the respondents strongly agreed whereas $85(37.6 \%)$ of them agreed that the NGOs utilized evaluation results. About $39(17.3 \%)$ of them were neutral on the issue indicating that they either agreed or disagreed with it. About 20 (8.8\%) disagreed with it whereas $10(4.4 \%)$ strongly disagreed with it. The mean utilization of the evaluation results in the organizations was thereby 3.85 with a standard deviation of 1.382. This composite mean score suggested that the respondents agreed that their organizations utilized the evaluation results. The respondents indicated that most of the organizations utilized evaluation results to scale up projects $($ mean $=4.09)$, restructure the projects $($ mean $=3.98)$ and staff members to learn more about the projects (mean $=3.97$ ) out of the evaluations conducted. The evaluation results, however, were least utilized to solicit for funds (mean $=3.43$ ), boost funding (mean $=3.67$ ) or even to sway interest into the projects (mean = 3.79).

The findings were in agreement with findings by Bourgeois and Whynot (2018) who established that evaluations were utilized for conceptual and instrumental purposes at programme level. Some of those purposes included authenticating the managements' concerns about the changes that needed to be implemented to enhance programmes' delivery and strategies. In line with Bourgeois and Whynot (2018), the respondents indicated that the NGOs utilized the evaluation results to scale up their projects, restructure them or enhance learning among staff members. The findings were also in agreement with Ramírez, et al. (2015) who established that the evaluation results were utilized to inform organizational operational and strategic decisions.

\subsection{Organizational Leadership Style}

Organizational leadership styles that were under consideration included Autocratic, Laissez-faire, Democratic, Transformational and Transactional leadership styles. The views of the respondents towards the influence of organizational leadership style on the utilization of evaluation results in the NGOs' projects were also assessed using ten statements. A similar Likert scale was utilized to determine the extent to which they agreed or disagreed with the statements. Table 3 provides the study's findings on the influence of organizational leadership style on utilization of evaluation results.

Table 3. Organizational leadership styles and utilization of evaluation results

\begin{tabular}{|c|c|c|c|c|c|c|c|}
\hline STATEMENTS & SA & $\mathbf{A}$ & $\mathbf{N}$ & $\mathbf{D}$ & SD & Mean & Std. Dev. \\
\hline My manager does not consult staff & $9(4 \%)$ & $8(3.5 \%)$ & $18(8 \%)$ & $85(37.6 \%)$ & $106(46.9 \%)$ & 4.20 & 1.007 \\
\hline $\begin{array}{l}\text { Staff are expected to obey without receiving } \\
\text { any explanation }\end{array}$ & $5(2.2 \%)$ & $14(6.2 \%)$ & $18(8 \%)$ & $87(38.5 \%)$ & $102(45.1 \%)$ & 4.18 & 0.974 \\
\hline Staff have complete freedom to make decision & $82(36.3 \%)$ & $88(38.9 \%)$ & $36(15.9 \%)$ & $15(6.7 \%)$ & $5(2.2 \%)$ & 4.00 & 0.996 \\
\hline $\begin{array}{l}\text { Staff are expected to solve problems on their } \\
\text { own }\end{array}$ & $18(8 \%)$ & $24(10.6 \%)$ & $80(35.4 \%)$ & $82(36.3 \%)$ & $22(9.7 \%)$ & 3.29 & 1.05 \\
\hline $\begin{array}{l}\text { Staff are encouraged to share ideas and } \\
\text { opinions }\end{array}$ & $89(39.4 \%)$ & $75(33.2 \%)$ & $28(12.3 \%)$ & $23(10.2 \%)$ & $11(4.9 \%)$ & 3.92 & 1.167 \\
\hline $\begin{array}{l}\text { Staff share decision making and } \\
\text { problem-solving responsibilities with staff }\end{array}$ & $78(34.5 \%)$ & $82(36.3 \%)$ & $36(15.9 \%)$ & $26(11.5 \%)$ & $4(1.8 \%)$ & 3.90 & 1.058 \\
\hline My manager leads by example & $54(23.9 \%)$ & $67(29.6 \%)$ & $59(26.1 \%)$ & $35(15.5 \%)$ & $11(4.9 \%)$ & 3.52 & 1.155 \\
\hline My manager provides clear objectives & $71(31.4 \%)$ & $84(37.1 \%)$ & $51(22.6 \%)$ & $11(4.9 \%)$ & $9(4.0 \%)$ & 3.87 & 1.040 \\
\hline $\begin{array}{l}\text { My manager rewards staff meeting set } \\
\text { performance targets }\end{array}$ & $79(35 \%)$ & $86(38.1 \%)$ & $29(12.8 \%)$ & $20(8.8 \%)$ & $12(5.3 \%)$ & 3.88 & 1.141 \\
\hline $\begin{array}{l}\text { My manager inspires staff through corrective } \\
\text { actions and rule enforcement }\end{array}$ & $70(31 \%)$ & $89(39.4 \%)$ & $40(17.7 \%)$ & $17(7.5 \%)$ & $10(4.4 \%)$ & 3.85 & 1.025 \\
\hline $\begin{array}{l}\text { Overall Composite Organizational } \\
\text { leadership styles }\end{array}$ & $56(24.8 \%)$ & $62(27.4 \%)$ & $40(17.7 \%)$ & $40(17.7 \%)$ & $28(12.4 \%)$ & 3.86 & 1.065 \\
\hline
\end{tabular}

The overall composite score of all indicators of Organizational leadership style revealed that $56(24.8 \%)$ of the respondents strongly agreed that leadership style had notable influence on the utilization of evaluation results, about $62(27.4 \%)$ of the respondents agreed with the statement, $40(17.7 \%)$ of them were neutral, $40(17.7 \%)$ disagreed whereas 28 (12.4\%) of them strongly disagreed with the statement. The overall composite means score and standard deviation for all the constructs of organizational leadership styles was 3.86 and 1.065 respectively, implying that the project staff were in agreement that organizational leadership style had notable influence on the utilization of evaluation results in the NGOs.

The study sought to determine the degree to which project staff agreed/disagreed with statements about the leadership style of their organizations. As shown on Table 3, the first statement had $(\mathrm{M}=4.20, \mathrm{SD}=1.407)$. It required the respondents' view on non-consultation of staff by the leadership in the organization, as an indicator 
autocratic leadership style, and out of 226 reached, the majority of the project staff $(84.5 \%)$ disagreed that their managers do not consult staff in the utilization of evaluation results. The mean score $(M=4.20, S D=1.007)$ was way above the composite one $(\mathrm{M}=3.86, \mathrm{SD}=1.065)$ implying that consultation of staff by the leadership in the organization style positively influenced the utilization of evaluation results in the NGOs. The findings imply that leadership style that promotes consulting with staff would positively influence utilization of evaluation results in the NGOs. This suggests management involvement which Khan et al. (2014) found to enhance the credibility of the $M \& E$ process and acceptance and use of the findings.

The second statement required the respondents' view on the leadership of the organization's expectation of staff to obey orders without receiving any explanation (autocratic leadership), and the majority (83.6\%) of the project staff at least disagreed that their managers expect staff to obey orders without receiving any explanation in the utilization of evaluation results. The mean score $(\mathrm{M}=4.18, \mathrm{SD}=0.974)$ was beyond the composite mean score $(\mathrm{M}=3.86, \mathrm{SD}=1.065)$ implying that leadership style that does not expect staff to obey orders after receiving explanation positively impacted the use of evaluation results in the NGOs. This is supported by the studies by Yukl (2001) who established that such leaders made decisions independently with minimal input from group members.

The study also required the respondents' view on allowance of complete freedom to make decisions by the leadership of the organization (laissez-faire leadership style) and most (38.9\%) of the project staff agreed that staff have complete freedom to make decision in the utilization of evaluation results. The mean score $(\mathrm{M}=3.29$, $\mathrm{SD}=1.05)$ was below the composite one $(\mathrm{M}=3.86, \mathrm{SD}=1.065)$ implying that leadership style allowing staffs to have complete freedom to make decision negatively influenced the utilization of evaluation results in the NGOs. This is confirmed by Ryan and Tipu (2013) who found that this kind of leadership leads to the lowest productivity among project staff.

The fourth statement required the respondents' view on the expectation by the leadership of the organization for the staff to solve problems independently (laissez-faire leadership style) and most (71.7\%) of the respondents least agreed that staff members were allowed to solve problems on their own in the utilization of evaluation results. The mean score $(\mathrm{M}=3.29, \mathrm{SD}=1.05)$ was slightly below the composite one $(\mathrm{M}=3.86, \mathrm{SD}=1.065)$ implying leadership style that expect staff to solve problems on their own negatively influence the use of evaluation results in the NGOs. The study results contradict finding by Balthasar (2009) who concluded that orientation toward the requirements of the organization leadership, who were potential users, was a necessary condition for the use of evaluations.

The fifth statement required the respondents' view on whether staffs in the organization are encouraged to share ideas and opinions by leadership in the organization (democratic leadership style) and out of 226 participants, the majority (72.6\%) of them least agreed that staffs are encouraged to share ideas and opinions. The mean score (M $=3.92, \mathrm{SD}=1.167)$ was above the composite one $(\mathrm{M}=3.86, \mathrm{SD}=1.065)$ implying that leadership style that encourages staff to share ideas and opinions positively influences the use of evaluation results in the NGOs. The results were in agreement with Jung (2001) who established that allowing input from other group members encourages staffs to share opinions and ideas even though managed retained final says on decision making processes.

The study also required the respondents' view on leadership in the organization sharing decision making and problem-solving responsibility with staff (democratic leadership) and the majority (70.8\%) of the respondents least agreed that their manager's shared decision making and problem-solving responsibility with staff in the utilization of evaluation results. The mean score $(M=3.90, S D=1.058)$ was above the composite one $(M=3.86$, $\mathrm{SD}=1.065)$ implying that that leaders style encouraging shared decision making and problem-solving responsibility with staff positively influences utilization of evaluation results in the organization. The study results were in agreement with finding Cousins et al. (2006) who found that instrumental and conceptual uses of evaluative inquiry occur in school settings in informal ways and support decision making among leaders.

The seventh statement sought respondents' view on leadership in the organization leading by example (transformational leadership style) and out of 226 participants, 54 (23.9\%) of the respondents strongly agreed, 67 (29.6\%) agreed, that their manager leads by example, 59 (26.1\%) were neutral, 35 (15.5\%) of them disagreed whereas $11(4.9 \%)$ of them strongly disagreed that their manager leads by example. This finding implied that most project staff agreed that their manager leads by example in the utilization of evaluation results. The mean score $(\mathrm{M}=3.52, \mathrm{SD}=1.155)$ was slightly below the composite one $(\mathrm{M}=3.86, \mathrm{SD}=1.065)$ implying that leadership style in which managers do not lead by example negatively influence utilization of evaluation results in the organization. This is contrary to findings by Pieterse et al. (2010) that suggests leaders who articulate the 
change needs, develop new vision, mobilize commitment and arouse followers to deliver extraordinary results are likely to inspire followers to use evaluation results. They recognised significant connections between transformational leadership and innovative actions in their study.

The eighth statement sought the respondents' perception on the provision of clear objectives (transactional leadership style) by the leadership in the organization and the majority $(68.5 \%)$ of the respondents agreed that their manager provides clear objectives for the utilization of evaluation results. The mean score $(\mathrm{M}=3.87, \mathrm{SD}=$ 1.04) was above the composite one $(\mathrm{M}=3.86, \mathrm{SD}=1.065)$ implying that leadership style in which manager provides clear objectives (transformational leadership) positively influences the use of evaluation results in the NGOs. The study results support the conclusions by Ryan and Tipu (2013) who identify transformational leaders as able to outline and articulate an imaginative and prescient goal for their agencies. Such a leader will easily influence staff to utilize evaluation results.

Statement nine sought to establish the respondents' view on rewards to staff by leadership in the organization for meeting set performance targets (transactional leadership style) and the majority (73.1\%) agreed that their manager rewards staff meeting performance set targets in the utilization of evaluation results. The mean score (M $=3.88, \mathrm{SD}=1.141)$ was above the composite one $(\mathrm{M}=3.86, \mathrm{SD}=1.065)$ implying that leadership style in which a manager rewards staff for meeting set performance targets moderately impact the use of evaluation results in the NGOs. Transactional leadership style therefore positively influences the utilization of evaluation results in the organization.

The last statement needed to determine the project staff's view on staff inspiration through corrective actions and rule enforcement and out of 226 participants, the majority (70.4\%) agreed that their manager inspires staff through corrective actions and rule enforcement in the utilization of evaluation results. The mean score $(\mathrm{M}=$ $3.85, \mathrm{SD}=1.025$ ) was nearly the same as 3.86 and standard deviation of 1.065 implying that transactional leadership style moderately impacted by the use of evaluation results in the NGOs.

The managers in the NGOs mostly do not consult staff (mean $=4.20$ ), staff are supposed to follow rules without receiving any explanation (mean $=4.18$ ) yet have complete freedom to make decisions $($ mean $=4.00)$. Staff in the organizations are less expected staff to solve problems on their own (mean $=3.29)$, managers lead less by example (mean $=3.52)$ and do not inspire staff much through corrective actions and rule enforcement (mean = 3.85).

The above findings on the influence of Organizational leadership styles on Utilization of evaluation results are in agreement with Cousins et al. (2006) who found out that leadership style influences the utilization of evaluation results. The findings are also similar to findings by Balthasar (2009) who also found that the needs of the organization leadership, thus organizational leadership styles, influence utilization of evaluation. Similarly, Khan et al. (2014) found that the involvement of leadership enhanced evaluation use. Transformational leadership style has particularly been found to have a constructive relationship with project teams, therefore having a positive influence on success in the utilization of evaluation results (Gillard, 2009).

\subsection{Relationship Between Organizational Leadership Style and Utilization of Evaluation Results}

The research sought to establish the link between Organizational Leadership Style and Utilization of Evaluation Results. Also, it sought to test the hypothesis that presumed that the link between the two variables (Organizational leadership styles and Utilization of evaluation results in NGOs' projects) was not statistically significant. A valid conclusion was necessary to get a clear interpretation of the findings based on the proposed hypotheses. Pearson correlation coefficient between pairs of variables was used to determine correlation while simple and multiple linear regression analysis were used to determine the model equations. With the help of the Organizational leadership styles' aggregate score and the use of evaluation results' scale, a Pearson Product Moment Correlation ( $r$ ) was run on the SPSS program to determine if the link between the two variables was statistically significant at $95 \%$ confidence level. Table 4 provides the study's findings.

Table 4. Correlation between organizational leadership styles on utilization of evaluation results

\begin{tabular}{lll}
\hline & & Utilization of evaluation results \\
\hline Organizational leadership styles & Pearson correlation coefficient & $0.936^{*}$ \\
& Sig.(2-tailed) & 0.000 \\
& $\mathrm{~N}$ & 226 \\
\hline
\end{tabular}

Note. ${ }^{\mathrm{p}}<.05$. 
The correlation output Table 4 provides an $r=0.936$ suggesting that the linear correlation between Organizational Leadership style and Utilization of evaluation results is positive and strong. The positive correlation obtained is in agreement with the descriptive statistics provided in Table 4 that depicted that the respondents agreed $(M e a n=3.86)$ that organizational leadership style enhances the use of evaluation results in NGOs.

These findings imply that the use of evaluation results among NGOs based in Kisumu Central Sub-county is correlated with leadership style. Cousins et al. (2006) also found that school leadership style and evaluation use are correlated. Balthasar (2009) as well concluded that alignment of evaluations to organization leadership's requirement was a necessary condition for the use of evaluations.

\subsection{Hypothesis Testing}

The study sought to test the hypothesis that there is no statistically significant relationship between Organizational leadership styles and Utilization of evaluation results in NGO projects in Kisumu Central Sub-County as follows:

H01: There is no statistically significant relationship between Organizational leadership styles and Utilization of evaluation results in NGO projects in Kisumu Central Sub-County.

The $p$ value was found to be 0.000 at 0.05 level of significance. This was less than 0.05 implying that there is a significant relationship among the variables. This led to the rejection of the null hypothesis and adoption of the alternative hypothesis that there is a significant relationship between Leadership style on Utilization of evaluation results in NGO projects in Kisumu Central Sub-County.

The research findings therefore conclude that there is a significant relationship between Leadership styles and Utilization of evaluation results in NGO projects in Kisumu Central Sub-County. The findings resemble those of Jiang (2014) who also established the presence of a relationship between a project manager's leadership style and its effect, or even regulation over, project success factors.

\subsection{Regression Analysis of Organizational Leadership Styles and Utilization of Evaluation Results}

Simple linear regression was adopted to investigate how Organizational leadership styles influence Utilization of evaluation results. The rationale of using the simple regression model was to establish how leadership style as a predictor significantly or insignificantly predicted Utilization of evaluation results. The regression results are presented in Table 5.

Table 5. Regression output of utilization of evaluation results on organizational leadership styles

\begin{tabular}{|c|c|c|c|c|c|c|}
\hline \multirow{2}{*}{$\begin{array}{l}\text { Model } \\
\text { summary }\end{array}$} & $\mathbf{R}$ & $\mathbf{R}^{2}$ & Adjusted $\mathbf{R}^{2}$ & \multicolumn{3}{|c|}{ Std. error of the estimate } \\
\hline & 0.936 & 0.877 & 0.876 & \multicolumn{3}{|c|}{0.389} \\
\hline \multicolumn{7}{|c|}{ ANOVA } \\
\hline & & Sum of squares & d.f & Mean square & $\mathbf{F}$ & Sig. \\
\hline & Regression & 241.024 & 1 & 241.024 & 1591.744 & 0.000 \\
\hline & Residual & 33.918 & 224 & 0.151 & & \\
\hline & Total & 274.942 & 225 & & & \\
\hline \multicolumn{7}{|c|}{$\begin{array}{c}\text { Model } \\
\text { co-efficient }\end{array}$} \\
\hline \multirow{2}{*}{\multicolumn{2}{|c|}{ Model }} & \multicolumn{2}{|c|}{ Un-standardized co-efficient } & \multicolumn{2}{|c|}{ Standardized co-efficient } & Sig. \\
\hline & & $\mathrm{B}$ & Std. error & Beta & $\mathrm{T}$ & \\
\hline & Constant & 1.275 & 0.069 & & 18.417 & 0.000 \\
\hline & $\begin{array}{l}\text { Organizational leadership } \\
\text { styles }\end{array}$ & 0.766 & 0.019 & 0.936 & 39.897 & 0.000 \\
\hline
\end{tabular}

Note. $\mathrm{R}=0.936, \mathrm{R}^{2}=0.877, \mathrm{R}^{2}$ adjusted $=0.876, \mathrm{Se}=0.389, \mathrm{~F}$-stat: 1591.744 on 1 and $224 \mathrm{df}$, $\mathrm{p}$-value $=0.000$.

The model summary table suggest that there is a positive correlation $(\mathrm{R}=0.936)$ between Leadership style and Utilization of evaluation result and those predicted by the regression model. In addition, the regression analysis revealed that the coefficient of determination is $\left(\mathrm{R}^{2}=0.877\right)$, suggesting that the amount of variance in the Utilization of evaluation result is explained by leadership style is $87.7 \%$. The results are consistent with the findings of studies done by Jiang (2014) that suggest significant relationships between Organizational leadership styles and Utilization of evaluation result. The ANOVA results indicated that F-statistics $(1,224)=1591.74$, is 
significant at $\mathrm{P}$ value $0.000<0.05$ implying that the regression model results in significantly better prediction of Utilization of evaluation results. The coefficients table presented P-values $(0.000)$ less than the level of significance $(0.05)$ hence the simple regression model is given as;

$$
Y=1.275+0.766 X_{1}
$$

Where:

$Y$ is Utilization of evaluation results and

$X_{I}$ is Organizational leadership styles.

The model shows that Organizational leadership styles, had statistical significance (P-value $0.000<.05$; t-statistics $18.417>1.96$ ), leading to a unit change of 0.766 in Utilization of evaluation results. These results are consistent with the findings of a study done by Cousins et al. (2006) that suggest significant relationships between Organizational leadership styles and Utilization of evaluation results. Their study established that improved school leadership is among the important factors that enhanced use.

During the interview sessions with respondents, one of the themes that arose was their knowledge and awareness on whether their organization's leadership have the ability to influence the group towards the realization of its goals and a respondent had this to say;

"My organization's leadership sets up goals and guides all staff towards the realization of such goals. We are clearly guided on which elements of the results to implement by the programs manager who is always keen to see us achieve the set goals." [Project staff from the organization]

Similar sentiments were echoed by another respondent whose comment on capability of organizational leadership in influencing group towards realization of its goals was that;

"The programs manager always supports us to ensure we all understand and work towards achieving the organizational goals. Once staff understand the purpose for our evaluations, they have always implemented the recommendations." [Respondent]

It can therefore be deduced that Organizational leadership styles influences the utilization of evaluation results in NGO projects in Kisumu Central Sub-County.

\section{Conclusions}

The study found that majority of the project staff agreed that there was utilization of evaluation results in their organizations and that organizational leadership style influences the utilization of evaluation results. Based on the hypothesis, it was concluded that there was a statistically significant relationship between organizational leadership styles and utilization of evaluation results. The model summary results also revealed that there is a positive correlation between leadership style and utilization of evaluation result and those predicted by the regression model. In addition, the variance in the utilization of evaluation result is explained by leadership style and the ANOVA results imply that the regression model results significant better prediction of utilization of evaluation results. The regression model indicated that organizational leadership styles, had statistical significance, leading to a unit change in utilization of evaluation results. The study has further demonstrated that democratic, transformational and transactional leadership styles enhances utilization of evaluation results.

Even as the need for accountability among NGOs remains important, the findings of this research suggest general modest levels of evaluation use. It would be useful to further explore the relationship between the drivers for utilization of evaluation results and the specific types of evaluation use. Prospective researchers may want to concentrate on one type of evaluation use and what influences that specific type of use.

\section{Acknowledgments}

The primary author of this research article is Edwin Ochieng Okul, a Ph.D. student in Project Planning and Management at The University of Nairobi, Kenya. Professor Raphael Ondeko Nyonje, a Senior Lecturer, School of Open, Distance and eLearning at The University of Nairobi, Kenya is the supervisor of the student's work.

The authors would like to acknowledge the contributions of all those who made this work possible. We appreciate the general support by Professor Dorothy Kyalo, the Associate Dean, School of Open, Distance and eLearning, The University of Nairobi, Kenya and Mr. Bernard Manyala for the technical help with data analysis.

\section{References}

African Water Facility. (2014). Project Appraisal Report, Innovative Sanitation Value Chain for the Un-sewered Urban Poor in Kisumu, Kenya. Retrieved March 15, 2017, from 
https:/www.africanwaterfacility.org/fileadmin/uploads/awf/Projects/AWFProject-Appraisal-Report-KENY A-KIWASCO.pdf

Ali, A. J., \& Ali, M. H. (2017). The Role of Leadership in Strategic Management. International Journal of Research - Granthaalayah, 5(5), 99-106. https://doi.org/10.29121/granthaalayah.v5.i5.2017.1841

Alkin, M. C. (2004). Evaluation roots: Tracing theorists'views and influences. Thousand Oaks, Calif.: Sage Publications.

Balthasar, A. (2009). Institutional Design and Utilization of Evaluation. A Contribution to a Theory of Evaluation Influence Based on Swiss Experience. Evaluation Review, 33(3), 226-256. https://doi.org/10.1177/0193841X08322068

Bass, B. M. (1997). The ethics of transformational leadership. KLSP: Transformational Leadership, Working Papers.

Bass, B. M., \& Avolio, B. J. (1993). Transformational Leadership and Organizational Culture. Public Administration Quarterly, 12.

BaTall, O. (2009). The Role of National, Regional and International Evaluation Organizations in Strengthening Country-led Monitoring and Evaluation Systems. In Segone, M.

Bourgeois, I., \& Whynot, J. (2018). Strategic Evaluation Utilization in the Canadian Federal Government. Canadian Journal of Program Evaluation, 32(3), 327-346. https://doi.org/10.3138/cjpe.43179

Boyle, R., \& Lemaire, D. (Eds.). Building effective evaluation capacity. New Brunswick, NJ: Transaction Publishing.

Burns, J. M. (1978). Leadership. New York: Harper \& Row.

Chaplowe, S. G. (2008). Monitoring and E valuation Planning: Guiding Tools. USA: Catholic Relief Services and American Red Cross.

Christie, C. A., \& Alkin, M. C. (2008). Evaluation theory tree re-examined. Studies in Educational Evaluation, 34, 131-135. https://doi.org/10.1016/j.stueduc.2008.07.001

Concern Worldwide. (2014). SQUEAC REPORT, OTP PROGRAM Kisumu East District, Kisumu County, Kenya Samuel Kirichu, February 2013. Retrieved March 15, 2017, from http://www.coverage-monitoring.org/wp-content/uploads/2015/07/Kisumu-East-OTP_-Feb-2013_-Kenya_SQUEAC.pdf

Cousins, J. B., Goh, S. C., \& Clark, S. (2006). Data use leads to data valuing: Evaluative inquiry for school decision making. Leadership and Policy in Schools, 5(2), 155-176. https://doi.org/10.1080/15700760500365468

Cronbach, L. J., \& Azuma, H. (1962). Internal-consistency reliability formulas applied to randomly sampled single-factor tests: An empirical comparison. Educational and Psychological Measurement, 22(4), 645-665. https://doi.org/10.1177/001316446202200401

Dessler, G., \& Starke, F. A. (2004). Management: Principles and practices for tomorrow's leaders (2nd ed.). Toronto, Ontario: Pearson Education Canada Inc.

European Policy Evaluation Consortium (EPEC). (2005). Study on the Use of Evaluation Results in the Commission. Final Report, Dossier no.1: Synthesis Report and Annexes.

Fleischer, D. N., \& Christie, C. A. (2009). Evaluation use: Results from a survey of U.S. American Evaluation Association members. American Journal of Evaluation, 30(2), 158-175. https://doi.org/10.1177/1098214008331009

Gary, T. H., \& Melvin, M. (2003). Beyond Use: Understanding Evaluation's Influence on Attitudes and Actions. American Journal of Evaluation, 24(3), 293-314. https://doi.org/10.1016/S1098-2140(03)00056-0

Gillard, S. (2009). Soft Skills and Technical Expertise of Effective Project Managers. Issues in Informing Science and Information Technology, 6, 723-729. https://doi.org/10.28945/1092

Goh, S. C., \& Richards, G. (1997). Benchmarking the learning capability of organizations. European Management Journal, 15(5), 575-583. https://doi.org/10.1016/S0263-2373(97)00036-4

Goldman, I., Mathe, J. E., Jacob, C., Hercules, A., Amisi, M., Buthelezi, T. et al. (2015). Developing South Africa's national evaluation policy and system: First lessons learned. African Evaluation Journal, 3(1). 
https://doi.org/10.4102/aej.v3i1.107

Greene, J. C. (1988). Stakeholder participation and utilization in program evaluation. Evaluation Review, 12(2), 91-116. https://doi.org/10.1177/0193841X8801200201

Guba, E. (1990). The paradigm dialog. Newbury Park, CA: Sage.

Guskey, T. R. (2000). Evaluating professional development. Thousand Oaks, CA: Corwin Press.

Henry, G. (2003). Influential evaluations. American Journal of Evaluation, 24(4), 515-524. https://doi.org/10.1016/j.ameval.2003.10.001

Johnson, K., Greenseid, L. O., Toal, S. A., King, J. A., Lawrenz, F., \& Volkov, B. (2009). Research on evaluation use: A review of the empirical literature from 1986 to 2005. American Journal of Evaluation, 30(3), 377-410. https://doi.org/10.1177/1098214009341660

Jung, D. I. (2001). Transformational and transactional leadership and their effects on creativity in groups. Creativity Research Journal, 13, 185-195. https://doi.org/10.1207/S15326934CRJ1302_6

Khan, M. S., Khan, I., \& Akhtar, B. Y. (2014). Styles of leadership and its impact upon the project success. Public Policy and Administration Research, 4(11), 48-52.

Kirori, G. N. (2015). Rural Development Policies in Kenya: A Descriptive Analysis Over 1970-2001 Period. European Journal of Business, Economics and Accountancy, 3(1).

Krejcie, R. V., \& Morgan, D. W. (1970). Determining sample size for research activities. Educational and Psychological Measurement, 30, 607-610. https://doi.org/10.1177/001316447003000308

Larfela, R. (2010). Discover your management styles. Nairobi: Longhorn Publishers. Sasa sema publications.

Lowden, C. (2005). Evaluating the impact of professional development. Journal of Research in Professional Learning.

Magno, C., \& Gonzales, R. D. L. C. (2011). Measurement and evaluation in the Philippine higher education: Trends and development. In E. Valenzuela (Ed.), UNESCO Policy Studies: Trends and development in Philippine Education. Manila: UNESCO.

Mark, M. M., Henry, G. T., \& Julnes, G. (2000). Evaluation: An integrated framework for understanding, guiding and improving policies and programmes. San Francisco: Jossey-Bass.

McCormick, E. R. (1997). Factors influencing the use of evaluation results. In Dissertation Abstracts International (Section A: The Humanities and Social Sciences, p. 58).

Mouton, C. (2010). The history of programme evaluation in South Africa. MPhil thesis, Faculty of Arts and Social Sciences. Sociology and Social Anthropology Department, University of Stellenbosch.

Mugenda, O. M., \& Mugenda, A. G. (2003). Research methods, qualitative and quantitative approaches. Nairobi: ACTS Press.

Muller, R., \& Turner, R. (2010). Leadership competency profiles of successful project managers. International Journal of Project Management, 28, 437-448. https://doi.org/10.1016/j.ijproman.2009.09.003

Nyonje, R., Kyalo, D., \& Mulwa, A. (2012). Monitoring and Evaluation of Projects and Programmes: A Hand Book for Students and Practitioners. Nairobi: Aura Books.

Ochanda, J. (2005). A study of strategic management practices in the Kenya public sector. Nairobi: Unpublished MBA project, School of Business, University of Nairobi.

Orodho, J. A. (2009). Techniques of writing research proposals and reports in education and social sciences. Nairobi: Kanezja publishers.

Patton, M. Q. (2008). Utilization Focused Evaluation (4th ed.). Thousand Oaks: Sage.

Phillips, S., Goldman, I., Gasa, N., Akhalwaya, I., \& Leon, B. (2014). A focus on M\&E of results: An example from the Presidency, South Africa. Journal of Development Effectiveness, 6(4), 392-406. https://doi.org/10.1080/19439342.2014.966453

Pieterse, A. N., Knippenberg, D. V., Schippers, M., \& Stam, D. (2010). Transformational and transactional leadership and innovative behavior: The moderating role of psychological empowerment. Journal of Organizational Behavior, 31, 609-623. https://doi.org/10.1002/job.650

Preskill, H., Zuckerman, B., \& Matthews, B. (2003). An Exploratory Study of Process Use: Results and 
Implications for Further Research. American Journal of Evaluation, 24(4), 423-442. https://doi.org/10.1177/109821400302400402

Ramírez, R., Kora, G., \& Shephard, D. (2015). Utilization Focused Developmental Evaluation: Learning Through Practice. Journal of Multi-Disciplinary Evaluation, 11(24).

Republic of Kenya. (2014). Second Annual Progress Report on the Implementation of the First Medium Term Plan (2008-2012), May 2011. Nairobi: Republic of Kenya.

Republic of Kenya. (2017). Performance Management Framework for County Governments. Council of Governors. Republic of Kenya.

Ryan, J. C., \& Tipu, S. A. (2013). Leadership effects on innovation propensity: A two-factor full range leadership model. Journal of Business Research, 66, 2116-2129. https://doi.org/10.1016/j.jbusres.2013.02.038

Scott, E. B. (2003). The role of transformational and transactional leadership in creating, sharing and exploiting organizational knowledge. Journal of Leadership \& Organization Studies, 9(4), 32-44. https://doi.org/10.1177/107179190300900403

Shadish, W. R., Cook, T. D., \& Leviton, L. C. (1991). Foundations of program evaluation: Theories of practice. Newbury Park, CA: Sage.

Shulha, L. M., \& Cousins, J. B. (1997). Evaluation use: Theory, research, and culture since 1986. American Journal of Evaluation, 18(3), 195-208. https://doi.org/10.1016/S0886-1633(97)90027-1

Stolyarenko, K. (2014). National evaluation policy in Canada, Parliamentary Forum for Development Evaluation. Retrieved August 2, 2020, from http://www.pfde.net/images/pdf/cs5.pdf

Stufflebeam, D. L., Madaus, G. F., \& Kellaghan, T. (2000). Evaluation models: Viewpoints on educational and human services evaluation (2nd ed.). Boston: Kluwer Academic Publishers.

Stufflebeam, D. L., \& Shinkfield, A. J. (2007). Evaluation theory, models, \& applications. San Francisco, CA: Jossey-Bass.

Trottier, T., Van Wart, M., \& Wang, X. (2008). Examining the Nature and Significance of Leadership in Government Organizations. Public Administration Review, 68(2), 319-333. https://doi.org/10.1111/j.1540-6210.2007.00865.x

United States Agency for International Development-USAID. (2014). Capacity Kenya End of Project Evaluation Final Report. Retrieved March 15, 2017, from http://pdf.usaid.gov/pdf_docs/pa00jrd2.pdf

Wanjiru, W. E. (2013). Determinants of Effective Monitoring and Evaluation Systems in Non-Governmental Organizations Within Nairobi County, Kenya. Kenyatta University Masters Dissertation. Unpublished thesis.

\section{Copyrights}

Copyright for this article is retained by the author, with first publication rights granted to the journal.

This is an open-access article distributed under the terms and conditions of the Creative Commons Attribution license (http://creativecommons.org/licenses/by/4.0/). 